\title{
General Pathway for One-Pot Synthesis of Trifluoromethyl- Containing 2-Amino-cycloalka[b][1,8]naphthyridines
}

\author{
Rosália Andrighetto (PG), Helio G. Bonacorso (PQ), Jussara Navarini (PG), Nícolas \\ Krüger (IC), Marcos A. P. Martins (PQ), Nilo Zanatta (PQ)
}

\begin{abstract}
Núcleo de Química de Heterociclos (NUQUIMHE), Departamento de Química, Universidade Federal de Santa Maria, 97105-900 - Santa Maria, RS. ${ }^{*}$-mail heliogb@base.ufsm.br (H.G. Bonacorso)
\end{abstract}

Keywords: Cycloalka[b][1,8]-naphthyridines, Cyclocondensation reactions, Trifluoromethyl group

\section{INTRODUCTION}

Among the nitrogenous heterocycles, naphthyridines and their derivatives represent an important class of organic molecules that attract interest due to their exceptionally broad spectrum of biological activities as well as their use as important binding units in the molecular design of synthetic receptors. ${ }^{1}$ Naphthyridine derivatives have attracted considerable attention primarily due to the presence of a 1,8-naphthyridine skeleton in many compounds which have been isolated from natural substances and because they exhibit various biological activities. $^{2}$ As a heterocyclic moiety, 1,8naphthyridine also deserves special interest as in its molecule, the arrangement of the nitrogen atoms is optimal for chelation of various metal cations, including lanthanide ions. ${ }^{3}$ Considering the importance of trifluoromethylated heterocycles, the purpose of this work is to report the results of a chemical behavior study of the reactions of 2 trifluoroacetyl-1-methoxycycloalkenes 1 with 2,6diaminopyridine (2,6-DAP). ${ }^{4}$

\section{RESULTS AND DISCUSSION}

Trifluoracetyl cycloalkenes 1 when added dropwise to $2,6-\mathrm{DAP}$ at a molar ratio of $1: 1$, in methanol as solvent at $0{ }^{\circ} \mathrm{C}$ for $2 \mathrm{~h}$ and then heating under reflux for $24 \mathrm{~h}$, produced trifluoromethyl substituted cycloalka[ $b][1,8]$ naphthyridines $(\mathbf{3 b}$-d) in a one-step reaction (Scheme 1). ${ }^{4}$ Unfortunately, the cyclization of 1a did not take place; the reaction conditions allowed only the isolation of enaminone $2 a$ in $43 \%$ yield. The synthesis of $3 a$, in $78 \%$ yield, was only possible from intramolecular cyclization reaction of enaminone $\mathbf{2 a}$ in polyphosphoric acid medium (PPA), as shown in Scheme 1. ${ }^{4}$

\section{CONCLUSION}

We developed the synthesis of trifluoromethyl substituted cycloalka[b][1,8]naphthyridines $\mathbf{3}$ as fused heteropolycycles from direct or indirect cyclocondensation reactions of 2-trifluoroacetyl-1methoxycycloalkenes 1 with 2,6-DAP (Scheme 1). ${ }^{4}$ Furthermore, we have been able to use cycloalkenes 1, for the first time, in the synthesis of trifluoromethylated 2-amino-1,8-naphthyridines, which possess a free amino group for further important derivatizations.

\section{ACKNOWLEDGEMENTS}

\section{CNPq-CAPES-FATEC}

\section{REFERENCES}

${ }^{1}$ Goswami, S.; Mukherjee, R.; Mukherjee, R.; Jana, S.; Maity, A. C.; Adak, A. K. Molecules 2005, 10, 929.

${ }^{2}$ Mekheimer, R. A.; Hameed, A. M. A.; Sadek, K. U. ARKIVOC 2007, xiii, 269.

${ }^{3} \mathrm{He}, \mathrm{C} . ;$ Lippard, S. J. Tetrahedron 2000, 56, 8245

${ }^{4}$ Bonacorso, H. G.; Andrighetto, R.; Krüger, N.; Zanatta, N.; Martins, M. A. P. Molecules, 2011, 16, 2817.<smiles>C#CC1Cc2nc3nc(N)ccc3c(C(F)(F)F)c2C1</smiles>

$3 b-d$

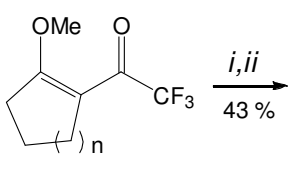

1a-d

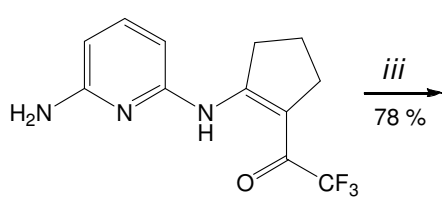

2a

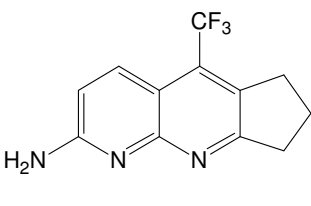

3a

$$
\begin{array}{c|cccc}
1-3 & \mathbf{a} & \mathbf{b} & \mathbf{c} & \mathbf{d} \\
\mathrm{n} & 1 & 2 & 3 & 8
\end{array}
$$

(i) = 2,6-Diaminopyridine (1.0 equiv.), $\mathrm{MeOH}, 0{ }^{\circ} \mathrm{C}, 2 \mathrm{~h}$; (ii) = MeOH, reflux, $24 \mathrm{~h}$; (iii) = PPA, $90{ }^{\circ} \mathrm{C}, 20 \mathrm{~h}$.

Scheme 1. Synthesis of trifluoromethyl substituted cycloalka[b][1,8]naphthyridines. 